\title{
"VOLCANIC EVENTS THAT HAVE MARKED THE ANTHROPIC HISTORY OF THE AEOLIAN ISLANDS,
}

\author{
Marco Manni*,1, Mauro Coltelli ${ }^{1}$, Maria Clara Martinelli ${ }^{2}$ \\ (1) Istituto Nazionale di Geofisica e Vulcanologia - Osservatorio Etneo, Catania, Italy \\ (2) Museo Archeologico Luigi Bernabò Brea, Lipari (Me), Italy
}

Article history

Receveid May 02, 2018; accepted September 24, 2018.

Subject classification:

Eolian Islands; Volcanic Eruptions; Prehistoric settlements; Historical Studies; Demographic Crises.

\begin{abstract}
Archaeological and historical studies, conducted since 1950, allow us to trace a hypothetical demographic framework in which three crises extended over time, attributed by scholars to unfavourable social-economic situations or to war aggression, can be observed. A comparison of these three crises with the volcanological record reveals a correlation suggesting that the volcanic events had an effect on local anthropic history.

The first crisis occurred in $4^{\text {th }}$ millennium BC and involved all the Aeolian Islands, particularly Contrada Diana, the main Neolithic site of Lipari. The Diana Spatarella facies records: the reduction of the coastal settlement of Contrada Diana, the settling of Rocca del Castello, and the development of settlements in areas protected from volcanic activity. These observations support the hypothesis that Contrada Diana was exposed to the effects of tsunami waves created by the Sciara del Fuoco collapse on Stromboli, and indirectly to the eruptions of Gran Cratere of Vulcano that also caused problems for the sailors travelling between the mainland to Lipari.

The second crisis occurred between $9^{\text {th }}$ and $6^{\text {th }}$ centuries BC and could be also be caused by the effects of the strong eruptive phase which occurred $2.9 \mathrm{ka}$ at Vulcano and the tsunami produced by another sector collapse on Stromboli at the end of the Neostromboli. As during the first crisis, navigation between the mainland and Lipari would have been made difficult.

The third crisis happened in the historical period between $6^{\text {th }}$ and $11^{\text {th }}$ centuries with a possible peak during the eruption of Monte Pilato which occurred in $776 \mathrm{AD}$ in the NE sector of Lipari.
\end{abstract}

\section{INTRODUCTION}

The importance of comparing archaeological data with the history of the Aeolian Islands volcanoes (Figure 1) was soon understood by Luigi Bernabò Brea and Madeleine Cavalier with the publication, in 1991, of the volume "Isole Eolie. Archeologia e Vulcanologia".

Since then, further research has provided new insights into the possible influence of volcanoes on the life of human communities: there is more information on the Aeolian volcanism and new geological maps with updated dates of lava flows. Additionally, archaeological research has also advanced, with new surveys, ex- cavations, and radiometric dates.

In Lipari, the largest island of the Aeolian archipelago, after the eruption of Vallone del Gabellotto, dated 8.7-8.4 ka [Zanchetta et al., 2011; Forni et al., 2013], a long phase of volcanic quiescence has allowed stable human settlements since the Middle Neolithic. Almost the entire archipelago was occupied at that time except for some periods of long lasting, in which the islands were almost uninhabited, or suffered a significant reduction in population, the causes of which are not yet fully known. These demographic crises have been generally attributable to cultural and environmental changes that involved southern Italy and, in a broader 


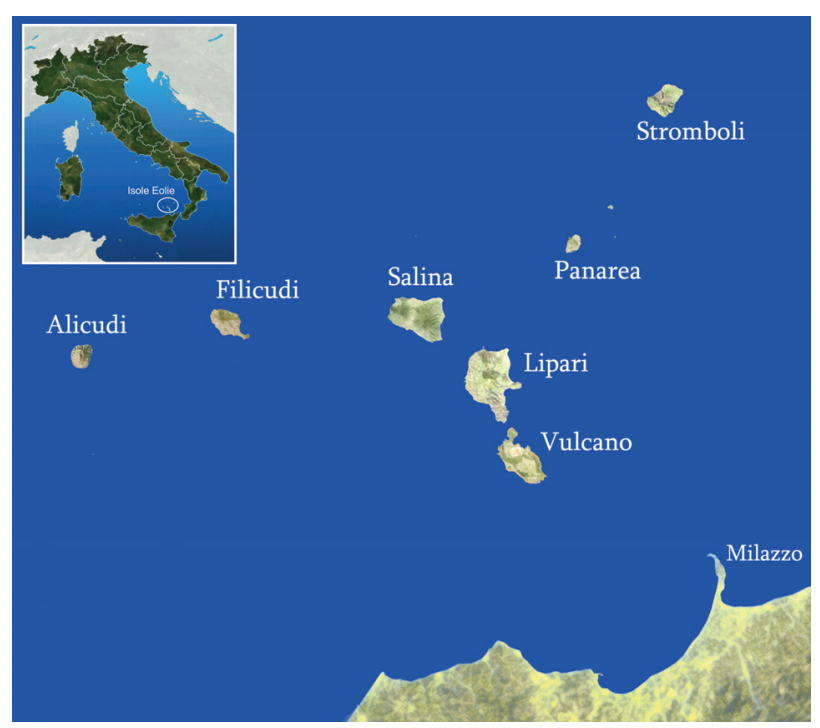

FIGURE 1. Geographic map of the Aeolian Island (Messina Italy).

sense, the whole Mediterranean. A specific analysis of the local factors is fundamental for the identification of possible causes of the demographic crisis, starting from the volcanic events that may have influenced the human behaviours of the indigenous communities. The temporary depopulation of a site and the contextual development of new settlements, in more internal areas or further away from active volcanic centres, may have been caused by the perception by the ancient populations of the risks connected to volcanic activity. While taking in to consideration the subsistence needs (agricultural exploitation), it cannot be excluded that these movements represent a response to the escalation of local volcanic phenomena.

It is well known that the Aeolian archipelago, in the last seven millennia in which there was a human presence, has been affected by catastrophic events capable of altering the delicate insular environment. This work will try to link volcanological and historical/archaeological data, in order to identify a possible correspondence between the catastrophic events due to the volcanic activity and the crisis situations of the human history in the frame of the cultural chronological development of the Aeolian Islands [Bernabò Brea and Cavalier, 1991c: 125-127; Martinelli, 2016; Levi et al., 2011]. The Neolithic and Copper Age has not been investigated with updated datings except for the initial phase of the Middle Neolithic (Stentinello II) [Martinelli, 2016: 264]. In the recent bibliography [Binder et al., 2017; Tinè and Natali, 2014; Fiorentino et al., 2013:1303; Pessina and Tinè, 2012: 47-48; Maniscalco, 2000: 504] the Middle Neolithic of southern Italy and
Sicily is dated between 5500-4500 BC and the Final Neolithic between 4500-3800 BC. These $\mathrm{C}^{14}$ dates would make the chronology of the Aeolian facies offset by at least 500 years earlier. In Table 1 the chronological phases of these periods have been elaborated considering this time space. Data discuss hereby are sufficient to formulate new hypotheses on the origin of the demographic crises, which need, however, additional information to be able to be confirmed or rejected the thesis illustrated in this paper.

\section{SUMMARY OF THE RECENT ERUPTIVE HISTORY OF AEOLIAN VOLCANOES}

The Aeolian Islands represent the subaerial part of an extended volcanic arc that rises from the depths of the southern Tyrrhenian Sea, northeast of Sicily (Figure 1). The volcanoes that produced eruptive activity during the period in question are: Lipari, Vulcano and Stromboli. The most recent eruptive activity of Lipari (Figure 2) has been concentrated in the northeastern sector of the island and is logged by the Vallone Fiume Bianco Synthem [Lucchi et al., 2013].

It started with the impressive eruption of Gabellotto - Fiume Bianco between 8.7-8.4 ka [Zanchetta et al., 2011] and $7.17 \mathrm{ka}$ [Bigazzi et al., 2003], which built a $130 \mathrm{~m}$ thick pyroclastic succession (Figure 2a) originating from a vent located just south of the present Monte Pilato cone. This eruption culminated with the emission of the Pomiciazzo obsidian-rich lava flow (Figure 2a), which provided the obsidian blocks whose artefacts were exploited since the Neolithic period and traded throughout the Mediterranean area. After a long period of quiescence, the eruptive activities resumed around $776 \mathrm{AD}$ [Keller, 2002] with the pumice eruption of Monte Pilato cone (Figure 2b), and the almost coeval obsidian flow of Forgia Vecchia [Forni et al., 2013]. During the $13^{\text {th }}$ century $\mathrm{AD}$, the last eruptive episode took place on the island forming the small parasitic cone of Lami and the large Rocche Rosse obsidian flow [Tanguy et al., 2002; Bigazzi et al., 2003].

On Vulcano Island, half a mile south of Lipari, in the same period volcanic activity was also in progress. The La Fossa caldera evolved in the last $10 \mathrm{ka}$ with the progressive shift of the eruptive centres towards the northern sector of the island, alternating periods of strong eruptive activity with periods of relative quiescence. In particular, between 8.5 and $8.3 \mathrm{ka}$ the formation of the 


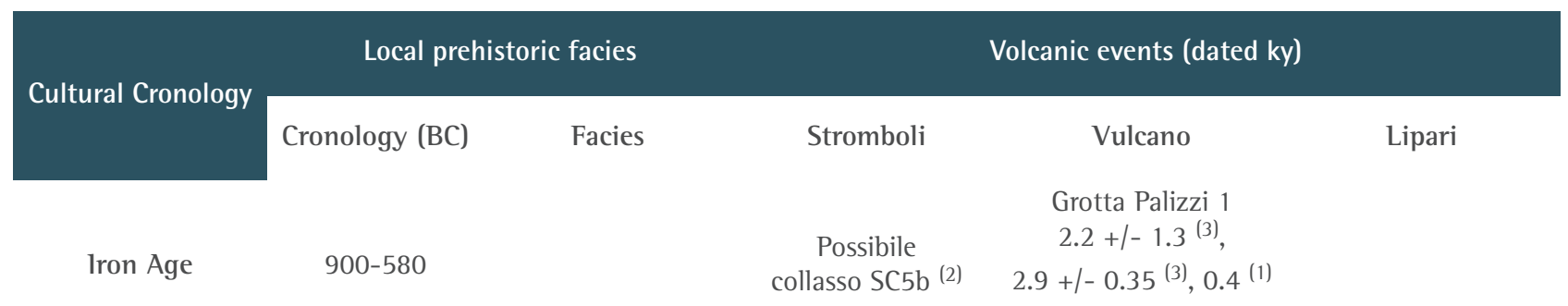

$\begin{array}{cccc}\text { Late Bronze age } & 1150-900 & \text { Ausonio } 11 & \\ \text { Recent Bronze age } & 1300-1150 & \text { Ausonio } 11 & \text { Semaforo Labronzo }\end{array}$

Middle Bronze age $3 \quad$ 1500-1300 Milazzese

Early and Middle

Bronze 2300-1500 Capo Graziano 1 e 11

age $1-2$

Serro Adorno

Late Copper Age $\quad$ 2500-2300 Piano Quartara $\quad 4.0 \pm 0.9^{(11)}$

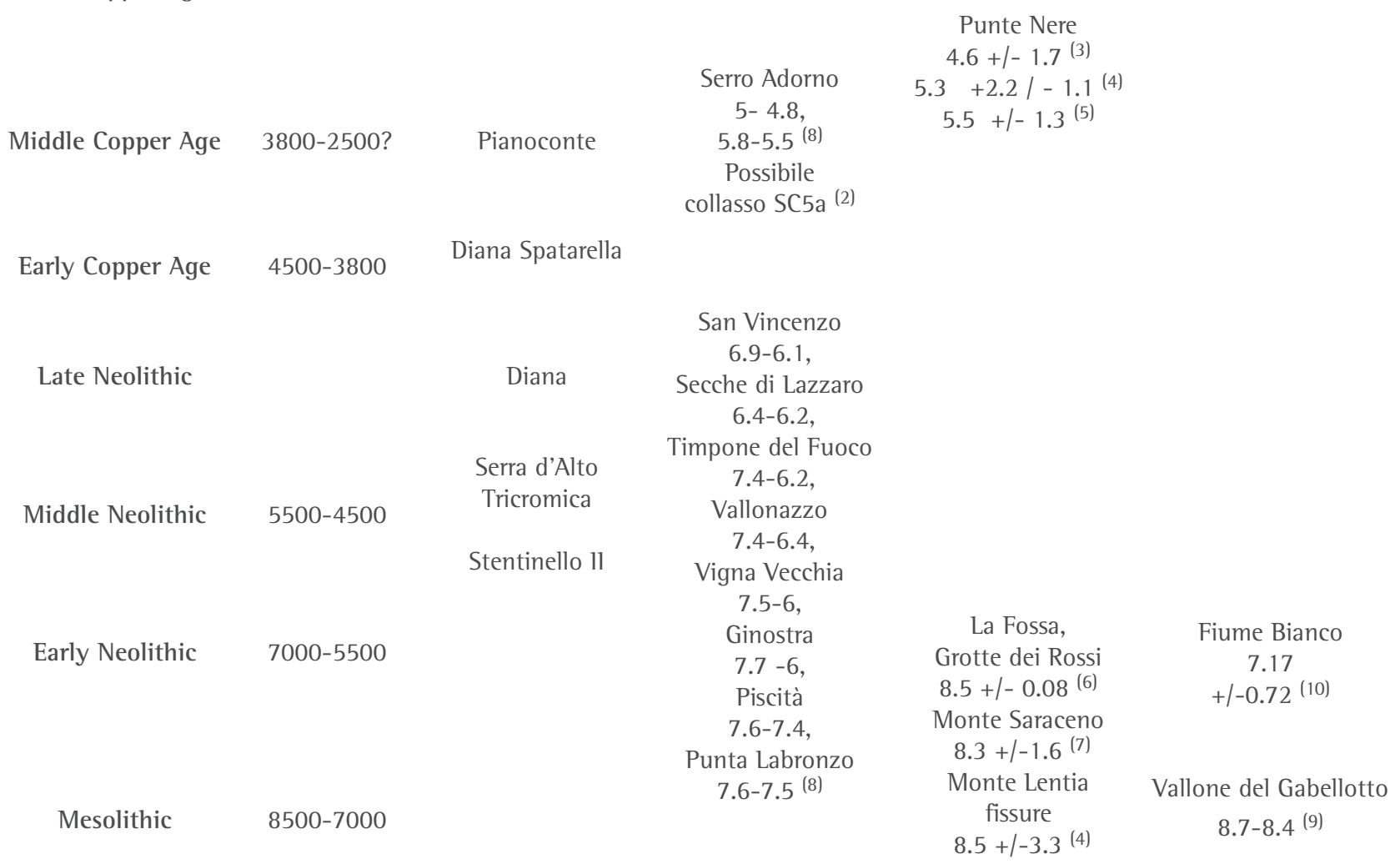

TABLE 1a. Comparison between archaeological and volcanological data from Mesolithic to Iron Age. 1.b) Comparison between archaeological and volcanological data from Greek Age to Middle Age. (the relationships between volcanic events and periods of crisis are highlight in reddish). References for the age determinations of the volcanic products: (1) Voltaggio et al., 1995; (2) Manni, 2015; (3) Frazzetta et al., 1985; (4) Soligo et al., 2000;(5) Gillot, 1987; (6) De Astis et al., 1997b; (7) De Astis et al., 1989; (8) Risica et al., 2017; (9) Zanchetta et al., 2011; (10) Bigazzi et al., 2003; (11) Calvari et al., 2011; (12) Keller, 1970; (13) Keller, 2002; (14) Tanguy et al., 2002; (15) Bigazzi and Bonadonna, 1973; (16) Arringhi et al., 2006; (17) Speranza et al., 2008; (18) Rosi et al., 2000. 


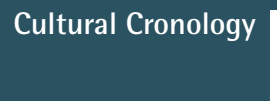

Period BC-AD

$1300-1000$

$838-500$

Byzantine (Byzantine monasticism)

Imperial Roman Age 500 AD -27 BC

$\begin{array}{lcc} & \begin{array}{c}\text { Roman } \\ (251-252 \mathrm{BC} \\ \text { Republican Roman } \\ \text { Age } \\ \text { conquest of Lipari) }\end{array} \\ & & \\ \text { Greek Age } & 580-252 \mathrm{BC} & \\ \end{array}$

TABLE $1 b$.

Lentia, Monte Saraceno and Piano Grotta dei Rossi centres erupted the Upper Brown Tuffs which were deposited on the entire archipelago, representing an important stratigraphic marker for the reconstruction of the eruptive history of the volcanic islands. After a period of quiescence, about $3 \mathrm{ka}$ long, in which was formed a red-orange paleosol, new eruptions concentrated at the centre of the caldera formed the Gran Cratere di La Fossa (hereafter Gran Cratere) tuff cone (Figure 3) during its first eruptive cycle, about 5.5 ka [Frazzetta et al., 1985; Gillot, 1987; Soligo et al., 2000].

A long series of hydromagmatic explosive eruptions, characterized by the emplacement of pyroclastic flows and surge deposits, led to the construction of the lower portion of the Gran Cratere (Figure 3). The first eruptive cycle ended 2.9 ka ago with the widespread surge de- posits of Grotta Palizzi 1 Formation [Voltaggio et al., 2015; De Astis et al., 2013]. The eruptive activity restarted to the north of the Gran Cratere forming Il Faraglione tuff cone and the basal part of the Vulcanello centre, both of which have similar compositions. The intermediate eruptive cycle of the Gran Cratere started about $2.2 \mathrm{ka}$ ago with the emplacement of the Grotta dei Palizzi 2 Formation, then continued until the Middle Ages producing the Grotta dei Palizzi 3 Formation and Caruggi Formation [De Astis et al., 2013]. In the early Middle Ages the eruptive activity resumed on the nearby island of Lipari, marked in the stratigraphy succession by the pumice fall deposit of Monte Pilato, dated to 776 AD by Keller [2002] and found within the Caruggi Formation of Vulcano. Once again the eruptive activity occurred north of the Gran Cratere forming the 

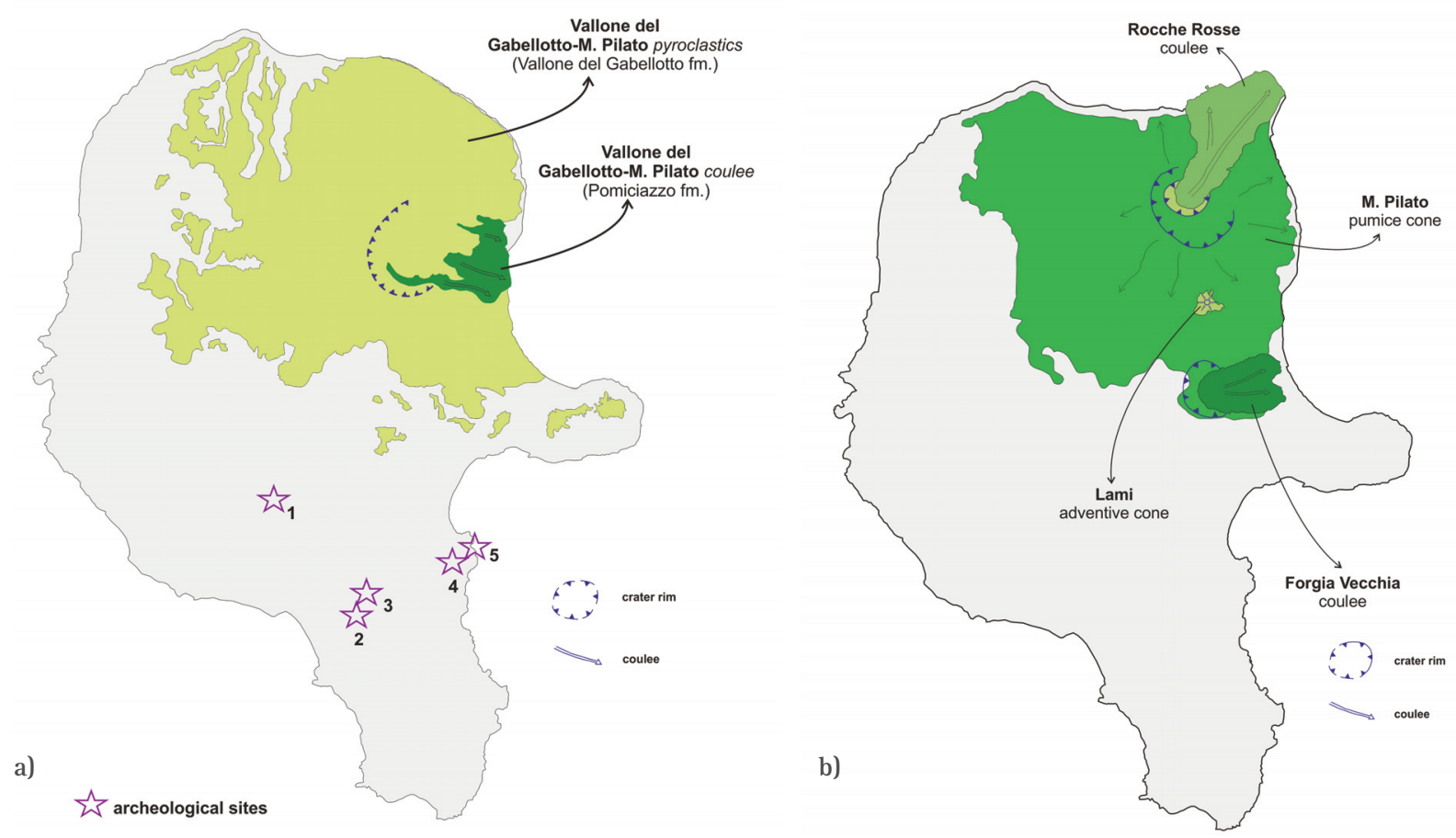

FIGURE 2. Lipari Island geological sketch map redrawn from Lucchi et al., [2013] of: a) Vallone del Gabellotto - M. Pilato eruption with Neolithic and Copper Age archaeological sites: 1) Pianoconte, 230-245 m a.s.l.; 2) Spatarella, 240 m a.s.l.; 3) Monte Giardina, 150-250 m a.s.l.; 4) Contrada Diana, $15 \mathrm{~m}$ a.s.l.; 5) Rocca del Castello-Acropoli, $40 \mathrm{~m}$ a.s.l. b) The eruptive cycle of M. Pilato, Forgia Vecchia and Rocche Rosse.

subaerial part of the Vulcanello centre in the $11^{\text {th }}$ and $12^{\text {th }}$ centuries, which was followed by a subsequent eruptive phase between the $16^{\text {th }}$ and $17^{\text {th }}$ centuries $[\mathrm{Ar}-$ righi et al., 2006]. The activity of the Gran Cratere restarted in 1739 after a long period of inactivity and continued during the $18^{\text {th }}$ and $19^{\text {th }}$ centuries until the last eruption occurred in 1888-90.

Stromboli volcano, the easternmost island of the archipelago (about 20 miles from Lipari), has been the object of continuous eruptive activity throughout the Neolithic period, concentrated mainly between 8 and 5 ka from the present [Francalanci et al., 2013], which led to an important evolution of the volcano called the Upper Neostromboli stage. In that time some lateral eruptions occurred (Figure 4): Nel Cannestrà, Punta Labronzo, Piscità, Vallonazzo, Timpone del Fuoco, Vigna Vecchia and San Vincenzo [the updated San Vincenzo age is $6.2 \mathrm{ka}$, Speranza et al., 2008; Risica et al., 2017] and then Serro Adorno [5.8-4.0 ka, Calvari et al., 2011; Risica et al., 2017].

The thick hydromagmatic deposits of Secche di Lazzaro, which were emplaced about $7 \mathrm{ka}$ ago [Francalanci et al., 2013] or more recently 6.4-6.2 ka, as reported by Risica et. al. [2017], seem to be related to the impressive collapse of the NE volcano sector that formed the steep slope known as the Sciara del Fuoco (Figure 4) and left the deep "sc5a" scar [Francalanci et al., 2013]. In the Late Neostromboli stage the eruptive activity concentrated at the top of Sciara del Fuoco, and terminated with a new collapse witnessed by the Semaforo Labronzo hydromagmatic deposits overlaying the Serra Adorno lava flow (Figure 4) and by the "sc5b" scar [Francalanci et al., 2013]. In the Middle Ages the typical persistent explosive activity called Strombolian began [Rosi et al., 2013] and was emitted from small vents located on the crater terrace just below Pizzo Sopra la Fossa, which is stratigraphically positioned after the Monte Pilato of Lipari pumice fall deposit [Francalanci et al., 2013].

\section{HISTORICAL FRAMEWORK FROM 5500 BC TO $1000 \mathrm{AD}$}

The long period of quiescence of the Lipari and Vulcano volcanoes between 7.5 and $5.5 \mathrm{ka}$ allowed the development of human settlements in the archipelago with the succession, during the Neolithic, of different cultural facies. At Lipari and Salina, stable settlements were established since the middle of the $6^{\text {th }}$ millennium 


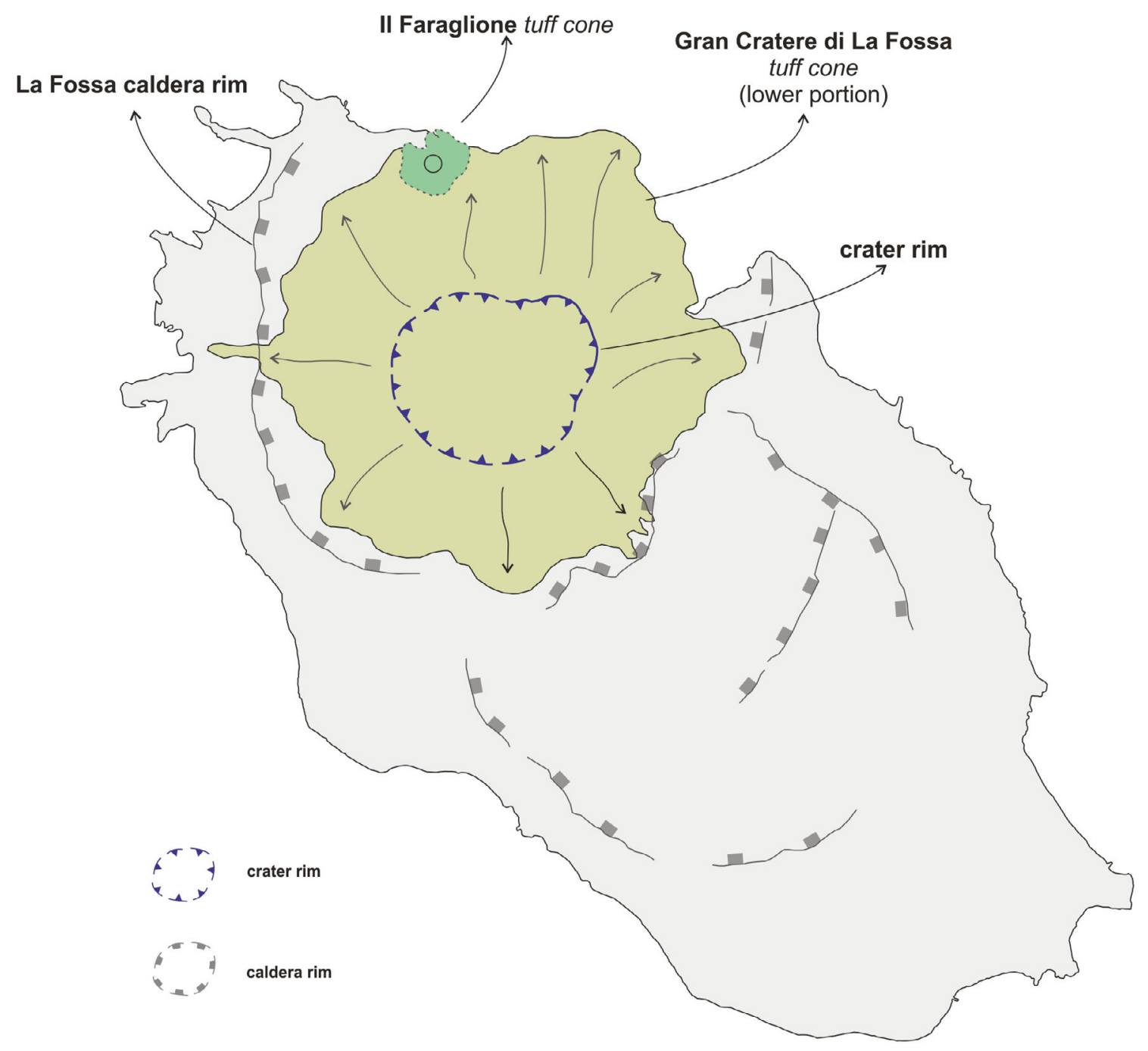

FIGURE 3. Vulcano Island geological sketch map, redrawn from De Astis et al., [2013], of the Gran Cratere di La Fossa, lower portion, and Il Farglione cone.

BC at Castellaro (Lipari) and at Rinicedda (Salina). On the island of Lipari, the archaeological study identifies the main evidence of cultural continuity with the complete prehistoric and protohistoric stratigraphic sequence.

The naturally fortified site on Rocca del Castello at Lipari (Figure 5) begins to be inhabited in the $5^{\text {th }}$ millennium BC (cultural aspects characterized by painted pottery: Tricromic and Serra d'Alto).

During the $5^{\text {th }}$ millennium BC the flourishing Diana culture benefited from the systematic exploitation of obsidian (Pomiciazzo area) and trade of this precious raw material. In this phase, in addition to the large village that occupied the plain of the Contrada Diana at Lipari (Figure 5), settlements were established on all islands of the archipelago, suggesting an increase of population [Bernabò Brea and Cavalier, 1960; Cavalier, 1979]. At the beginning of the $4^{\text {th }}$ millennium, after the great diffusion of the Diana culture, the settlement moved again from the plain of Diana to the Rocca del Castello [Bernabò Brea, 1988: 471]. The Diana - Spatarella facies, named after the inland site on Monte Giardina, marks the beginning of the Chalcolithic and is characterized by the drastic reduction of inhabited sites lasting the whole $4^{\text {th }}$ millennium BC, with the Pianoconte (named after the south-western upland of Lipari) and Piano Quartara $f a-$ cies. We observe therefore the first crisis in the population of the archipelago. "While the four phases of the Neolithic civilization ... give the impression of a cultural continuity, at this point in the Aeolian stratigraphic series is clear that a break must be marked. The culture of Pianoconte, defined for the first time in Lipari, has been recognized in the eastern cusp of Sicily (while it is 


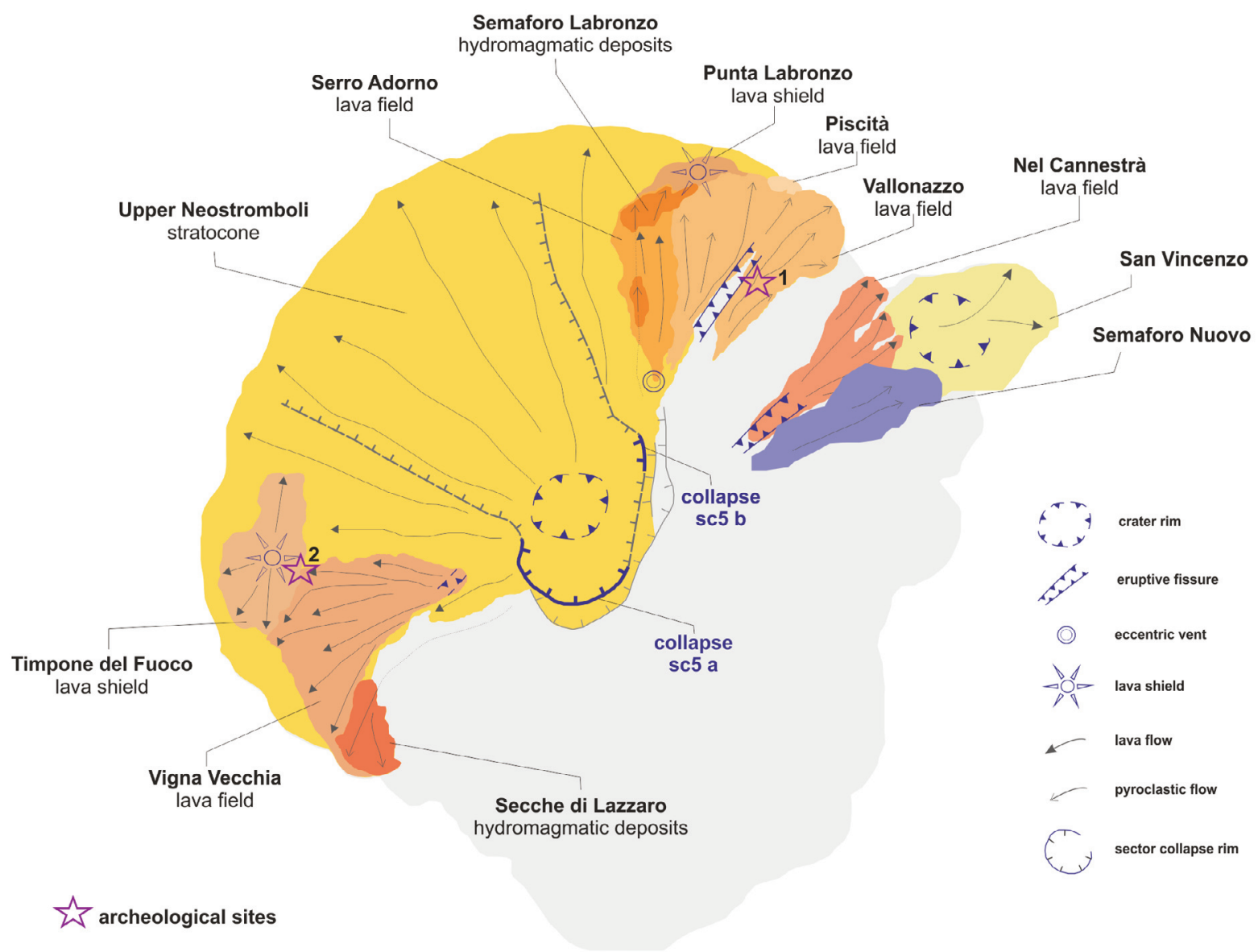

FIGURE 4. Stromboli Island geological sketch map, redrawn from Lucchi et al., [2013], of the Upper-Late Neostromboli with archaeological sites: 1) Serra Fareddu, 230 m a.s.l.; 2) Ginostra, Timpone del Fuoco, 140 m a.s.l.; 3) San Vincenzo, 70 m a.s.l.

extraneous to the other regions of the island) and in southern Italy (Calabria, Campania, Puglia, Salento), often represented by very small settlements, so that it seems to correspond everywhere to a period of strong demographic recession, of which we do not know the causes." [Bernabò Brea et al., 1994: 29; Bernabò Brea 1968-1969: 27]. This cultural change marks a contraction of the settlement below the Rocca del Castello of Lipari and, at the same time, the occupation of internal areas raised.

The advent of metals had a gradual impact on the exploitation of raw materials: the obsidian continued to be used until the Bronze Age in the archipelago and in surrounding areas. For example, at Ustica island [Foresta Martin and La Monica, 2017] is attested the importation and manufacture of obsidian from Lipari until in the Middle Bronze Age (1500 BC), a phase in which in the Aeolian island the obsidian is generally more rarely used. The obsidian disappeared at the end of the Bronze Age [Martinelli, 2010: 149].

The demographic concentration seems to remain at minimum values during the $4^{\text {th }}$ millennium BC, as evidenced by the reduced size of the settlements, even if at the first half of the $3^{\text {rd }}$ millennium, with the facies of Piano Quartara, there is a reversal trend with an increase of sites in Lipari, Salina, and Panarea [Martinelli et al., 2014].

The Bronze Age begins after 2300 BC with the Capo Graziano facies characterized by a new cultural and economic development. The importance of obsidian has declined but then became crucial for the geographical position of the archipelago in the middle of the lower Tyrrhenian Sea along the sea routes used by the Mycenaean aristocracies were protagonists in search of metals (copper and tin).

The Bronze Age is defined by the succession of different cultures (Capo Graziano, Milazzese and Ausonio) that extensively occupy the islands with large villages, mainly composed by stone oval-shaped huts [Bernabò Brea and Cavalier, 1968; 1980; 1991a; Martinelli et al., 2005; Bettelli et al., 2016; Levi et al., 2010; Levi et al., 


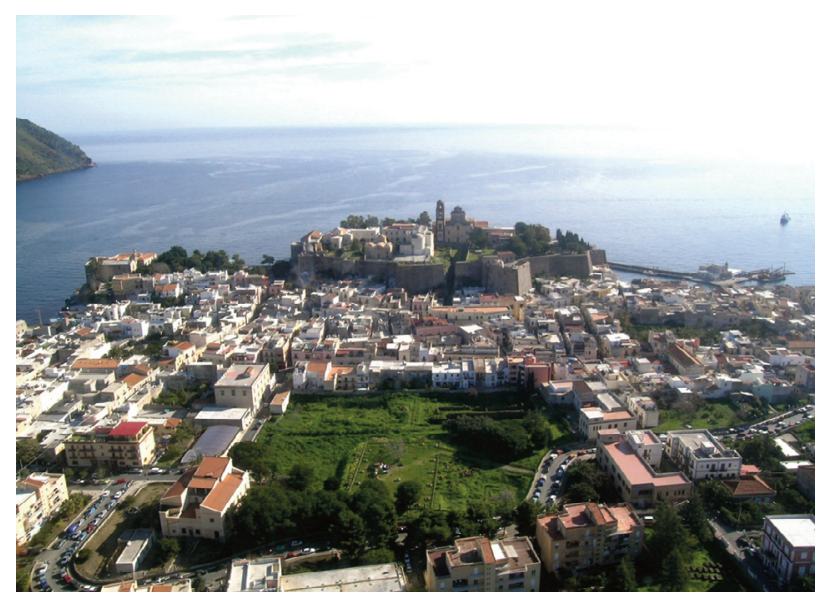

FIGURE 5. Rocca del Castello - Acropoli and Contrada Diana plain at Lipari.

2017].

The Sicilian Thapsos-Milazzese facies (1500-1300 BC) [Bernabò Brea and Cavalier, 1968, 1980; Martinelli, 2005; 2010] is characterized by perched and defended settlements placed on each island. During the Late Bronze Age (1300-900 BC) the Ausonio people come from the Italian peninsula to put an end to the previous villages and to occupy only the Rocca del Castello in Lipari [Bernabò Brea and Cavalier, 1980].

The second demographic crisis sees two main moments: the first one during the Ausonio facies in which only the island of Lipari is occupied, the second one when also this settlement was destroyed. Later, from 900 to 580 B.C. the Aeolian islands were almost uninhabited [Bernabò Brea and Cavalier, 1980].

In 580 BC the Greeks arrived on Lipari and, according to Diodorus Siculus (V 9.4), the local community founded by Aeolus was reduced to only 500 people, and so the Greeks were welcomed amicably and persuaded by the natives to settle. On the contrary, according to Pausanias $(\mathrm{X}-11,4)$, the islands called Aeolus, were instead uninhabited. However, the historical sources suggest broadly that the Aeolian archipelago was sparsely populated.

In Greek and Roman age, the Aeolian Islands have a new phase of constant development linked to economic and social wealth. A new disruption occurred with the earthquake that damaged the city of Lipari in the second half of $4^{\text {th }}$ century AD [Guidoboni et al., 2018]. The buildings, well known thermal baths of San Calogero, were abandoned during the period of Valente and Valentiniano I emperors (364-378 AD) as attested two roman coins found in debris layer of the destruction [Bernabò
Brea and Cavalier, 2003].

Archaeological evidence of the period following the earthquake, testify that in the $5^{\text {th }}-6^{\text {th }}$ century $\mathrm{AD}$ the settlements occupied naturally protected areas in internal uplands, mostly developed on previous Roman sites, determining a continuity of life until $6^{\text {th }}$ century $\mathrm{AD}$. The best testimonies come from Lipari and Salina [Bernabò Brea and Kronig, 1979; Bernabò Brea, 1989].

From the $6^{\text {th }}$ century $\mathrm{AD}$, the archaeological data are lacking because of the more recent events which transformed the settlements, deleting the testimony related to the $7^{\text {th }}-11^{\text {th }}$ centuries [Bernabò Brea, 1989: 125]. In this period, and particularly in $8^{\text {th }}-9^{\text {th }}$ centuries, a third crisis could be recognized.

Among the little evidence available there is the historical testimony of the Bishop who resided in Salina, together with the monks and a large part of the population of Lipari, to find shelter from the Saracen raids and especially from the volcanic activity of Lipari and Vulcano. San Willibald visiting Lipari witnessed the eruption of Monte Pilato di Lipari in 729 AD.

The interpretation of the Islamic presence in Lipari is controversial: they settled the island in $838 \mathrm{AD}$ after a violent incursion during which the inhabitants were deported, the church of San Bartolomeo on the Rocca del Castello was destroyed and the relics of the saint were dispersed: Lipari remained almost deserted except a small village on the Rocca del Castello [Zagari, 2015]. The events that followed this historical phase are not object of this work and for their articulation a specific study will be needed.

\section{DEMOGRAPHIC CRISES AND POSSIBLE IN- FLUENCE OF THE VOLCANIC ACTIVITY}

The demographic population of Lipari in the past has been estimated by some scholars [Arena, 1991; Iacolino, 2007]. It is difficult to consider numerical estimates, even if in hypothetical form, especially for the prehistoric and protohistoric phases. The only numeric data published is that of the village of Portella at Salina of the Middle Bronze Age III, calculated on the basis of the complete study of the context (excavation in extension) and ethnographic comparisons: the authors have proposed the presence of about 200 inhabitants [see page 212 of Martinelli, 2010].

To estimate the number of inhabitants considering the relationship between settlements and population we must 
consider also several local variables: agricultural use of the soil, domestic cattle, scarce presence of water reserves, location and size of the settlements [D’Oronzo et al., 2018].

The statistic analysis requires a reference sample that, in our case, is the oldest available census of the population of Lipari occurred in 1610 [Arena, 1995]. The value of 3000 people was also used by Arena for the first demographic hypothesis [see page 141 of Arena, 1991]. This number is not acceptable for the prehistoric and protohistoric phase from the Neolithic to the Iron Age; considering 200 people in each village, a maximum population of 500 individuals could be assumed in times of greater prosperity [Bernabò Brea and Cavalier, 1960, 1980].

We propose two graphs of the population of Lipari: the first one based on a population of 500 individuals for the chronological period 5000-600 BC (Figure 6); the second one on 3000 people starting from $400 \mathrm{BC}$ up to $1600 \mathrm{AD}$ (Figure 7).

In the first graph (Figure 6) we have approximately considered the date $600 \mathrm{BC}$ as the beginning of the Greek Age. The historical dates of foundation of Lipari are 580/579 BC according to Diodoro, and 629/626 BC according to San Girolamo and Eusebio [see pages VIII, 71, 72 of Pagliara, 1995].

The most ancient archaeological materials related to Greek people, found on the Acropolis of Lipari, attest to the presence of the Greeks in the $6^{\text {th }}$ century BC. We can hypothesize an increase in population from this period with the settlement of the settlers Cnidii and Rhodes.

The hypothesis formulated intends to highlight the cultural phases characterized by a reduction of the settlements and, therefore, hypothetically of the population:

- First crisis: $4^{\text {th }}$ millennium BC;

- Second crisis: $9^{\text {th }}-6^{\text {th }}$ centuries BC;

- Third crisis: $6^{\text {th }}-11^{\text {th }}$ centuries AD.

The first two crises are discussed in the following paragraphs while for the third one we present only a synthesis of the problems and it will be developed in a future study.

\subsection{THE FIRST CRISIS IN THE $4^{\text {TH }}$ MILLENNIUM BC, THE GRAN CRATERE OF VULCANO AND THE SCIARA DEL FUOCO COLLAPSE OF STROMBOLI}

In the $4^{\text {th }}$ millennium BC the settlements known are at Lipari (6), Salina (1) and Stromboli (3). Only in two sites, Acropoli at Lipari and Serro Brigadiere at Salina, is cultural and stratigraphic continuity attested to between Diana-Spatarella and Pianoconte facies (Figure 2a).
Between 3800 and $2500 \mathrm{BC}$, the islands may not be inhabited in some years probably due to the strong eruptive activity in the nearby Vulcano island. In fact, after 3 ka of dormancy, about 5.5 ka ago, the eruptive activity resumed at the centre of the La Fossa caldera of Vulcano. This phenomenon certainly had a negative impact on the normal course of the local anthropic history. The navigation from Sicily to Lipari [Kapitan, 2003] driven along the coasts (cabotage), using the islands as a stopover on the south Tyrrhenian routes, was certainly conditioned by the sudden occurrence of hydromagmatic explosions produced in the shallow water of the La Fossa caldera. The sea loch involved was that between Lipari and Vulcano, particularly dangerous in correspondence of the present Porto Levante and Faraglione where small eruptive centres erupted at that time. Volcano island, which has always been uninhabited, has been occasionally frequented in ancient times by the inhabitants of the nearby Lipari for agricultural works, hunting and quarrying of alum and sulphur.

On the Lipari island the main prehistoric site was the Contrada Diana, intensely inhabited in Neolithic $\left(5^{\text {th }}\right.$ millennium BC), which represented the epoch of maximum demographic expansion reached in Lipari during the prehistory. It is located just $6 \mathrm{~km}$ Nord from the area of the Gran Cratere, and was vulnerable to the effects of its explosive activity, lacking natural barriers (hills), especially when the wind blowing from the south caused ash fallout on the southern coast of Lipari. During the Neolithic all the Aeolian islands (except Vulcano) show new settlements born to satisfy the increased material needs of an increasing population. Conversely, in the Copper Age $\left(4^{\text {th }}-3^{\text {th }}\right.$ millennium BC) a drastic reduction of both number and size of the individual villages is attested. The Contrada Diana site continued to be inhabited but with small groups of huts.

The first demographic crisis (Table 1a; Figure 6) is recorded from the beginning of the Copper Age when the Rocca del Castello of Lipari was occupied again, a high and naturally defensible place that during the Neolithic facies of Diana had not been inhabited. At the same time the rural site of Spatarella was built close to Monte Giardina and protected by Monte Guardia to the South, as a natural barrier on the axis in between Vulcano and Lipari (Cavalier 1979 see pages 81-99, Martinelli 2001). This area, due to its morphology, could be considered safer and protected from the effects of the eruptions from Gran Cratere of Vulcano. If this consideration is valid, a correlation between volcanic 


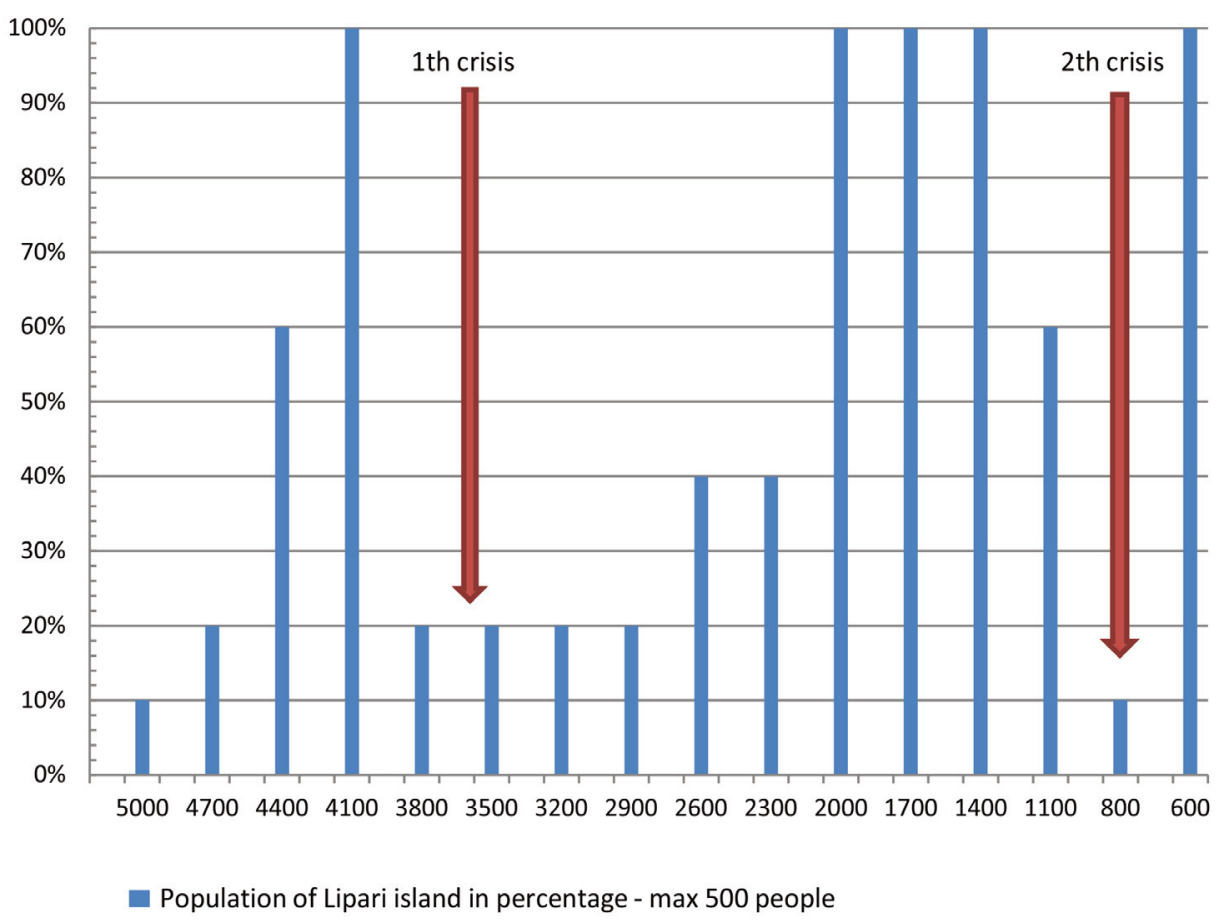

FIGURE 6. Demographic hypothesis of the population of Lipari from 5000 to $600 \mathrm{BC}$ calculated on the estimate of 500 individuals. The date $600 \mathrm{BC}$ corresponds to the historical chronology of the Greek people arrival at Lipari.

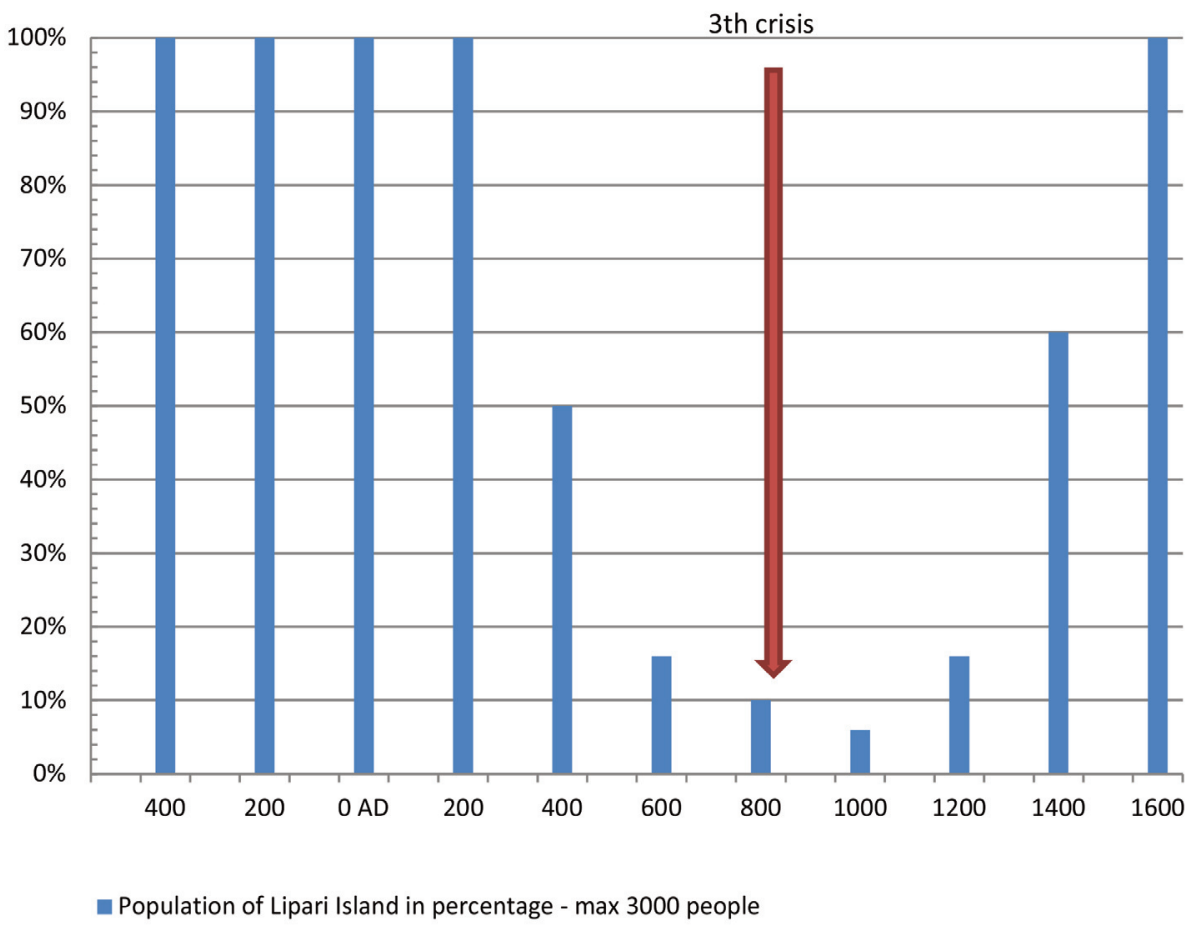

FIGURE 7. Demographic hypothesis of the population of Lipari from $400 \mathrm{BC}$ to $1600 \mathrm{AD}$ calculated on the estimate of 3000 individuals.

events and anthropic dynamics may be possible. Security reasons could have driven the Copper Age populations (Diana-Spatarella and Pianoconte facies) between the half of $4^{\text {th }}$ and the half of $3^{\text {th }}$ millennium BC to keep at distance the Vulcano Island, which, during the formation of the Gran Cratere, experienced one of the most 
dangerous times of its recent volcanic history.

The extent of volcanic activity of Stromboli until 5 ka BP probably made the island uninhabitable during the Neolithic age. The most ancient settlements in uphill position are dated to the Copper Age: Serra Fareddu testified to the Pianoconte facies [Cavalier, 1979: 126132] and Ginostra [Bernabò Brea and Cavalier, 1968: 45-46] with the remains of Pianoconte and Piano Quartara facies (Figure 4). The datings of the lava flows (Table 1a) where the human settlements are located are: Ginostra on Timpone del Fuoco lavas (7.4- 6.2 ka) and Serra Fareddu on Nel Cannestrà lavas (7.9-7.7 ka). Consequently both sites arose after $4^{\text {th }}$ millenium BC. In fact, at the beginning of the $4^{\text {th }}$ millennium fragments of pottery from the site of San Vincenzo [Cavalier, 1981: 41] attest the first short visit of the man, during the facies of Diana-Spatarella.

Stromboli volcano reached the maximum volumetric expansion during Neostromboli stage, due to a continuous eruptive activity, and was affected by flank instability that produced impressive sector collapses, which formed the Sciara del Fuoco horseshoe-shaped scar. Numerical simulations have confirmed the potential catastrophic effects of the tsunamis generated by similar collapses from the NE sector of Stromboli (volumes of the order of $1 \mathrm{~km} 3$ ) on the entire Aeolian Islands, Calabrian and Sicilian coasts [Tinti et al., 2002]. Two phreatomagmatic eruptions, presumably triggered by flank collapses, occurred between about 7000 and 2400 years ago, towards the end of the Upper Neostromboli and the beginning of the Pizzo stage [Francalanci et al., 2013]. The finding of hydromagmatic deposits at Secche di Lazzaro dated between 7 and 6 ka ago, allows Francalanci et al. [2013] to infer that a large sector collapse formed the Sciara del Fuoco.

At the beginning of Copper Age while Stromboli was probably inhabited with a small site (San Vincenzo), the sector collapse certainly caused large tsunami waves that travelled up to Lipari where the site of Contrada Diana occupied a lowland in contact with the sea bounded by docks, vulnerable to tsunamis waves [Manni, 2015]. If we consider that the Aeolian Islands during the $4^{\text {th }}$ millennium BC was affected by a strong volcanic activity, we could hypothesize that the facies of Diana Spatarella and Pianoconte were represented not only by a few smaller settlements far from the coastal plains, but also inhabited for short time. Therefore, archaeology can refine the age of this Stromboli catastrophic collapse close to about $6 \mathrm{ka}$ before present.

\subsection{THE SECOND CRISIS IN THE $9^{\text {TH }}$ CENTURY BC, THE GRAN CRATERE OF VULCANO AND THE SCIARA DEL FUOCO COLLAPSE OF STROMBOLI}

The second crisis (Table 1a; Figure 6), recorded between the $9^{\text {th }}-6^{\text {th }}$ centuries BC, begins with the destruction and abandonment of the Ausonio II town on the Rocca del Castello destroyed by fires and collapses of the huts. From this time a general state of abandonment affects the archipelago that may have been vulnerable to disastrous natural events. It cannot be excluded that relevant volcanic phenomena have locally burdened this crisis, however, caused by multiple social, economic and cultural factors that went ahead up to the Greek foundation of sixty century BC. We think about the eruptive activity of Vulcano that produced around 2.9 ka the widespread surge deposits of (Grotta Palizzi 1 Formation) and Il Faraglione tuff cone located on the coast, and, moreover, to the most recent sector collapse of Neostromboli witnessed by the Semaforo Labronzo hydromagmatic deposits that ended the Late Neostromboli eruptive stage [Francalanci et al., 2013]. In particular, the effects of the eruptive activity of Vulcano, as for the first crisis, could have determined further risks for the navigation, limited the connection with Sicily, and then complicated the living in Lipari inhabitants. As long as there was the need to inhabit Lipari, first for the obsidian trade and then as a port along the trade routes of the Bronze age, the human communities faced the risk of the navigation near an active volcano with frequent and unpredictable eruptions. It can be deduced that during the second crisis in 900 BC, the hostility of the volcano activity was no longer dealt with because the socio-economic conditions of the occupation of Lipari had disappeared.

\subsection{THE THIRD CRISIS OF THE EARLY MIDDLE AGES, THE ERUPTIONS IN THE NE SECTOR OF LIPARI}

The third major demographic crisis (Table $1 \mathrm{~b}$; Figure 7 ), occurred from the $6^{\text {th }}$ to the $11^{\text {th }}$ century, will be dealt with in more detail in a future work; here we are beginning the discussion on its causes. It could be imputable to historical and socio-economic facts, to the effects of the earthquake of $4^{\text {th }}$ century, to the resuming of the volcanic activity in Vulcano (Grotta Palizzi 3 and Caruggi formations) and in the NE sector of Lipari during the $6^{\text {th }}$ century, that has created, from the $8^{\text {th }}$ century, the eruptive centres of Monte Pilato (Figure 2b). The archaeological traces attest to the presence of settlements in rural areas on the internal plains of Lipari, 
less exposed to volcanic activity. Some places of Lipari retain traces of Byzantine culture in their local names: Piano Greca, San Calogero, San Basilio, Monte Sant'Angelo, Colle Sant'Eremo, etc. [Iacolino 2007]. In the same period on the island of Salina (which lies about two miles north of Lipari) several new sites were inhabited in Val di Chiesa and Vallone Castagno, probably for the migration of a part of Lipari population to more safe sites. In the NE sector of Lipari, the volcanic activity continued until the $13^{\text {th }}$ century [Tanguy et al., 2002; Bigazzi et al., 2003] changing considerably the landscape of this part of the island, and preventing any possibility of settlement and agricultural activity for several centuries.

\section{CONCLUSIVE REMARKS}

The analysis of archaeological and historical studies, conducted since 1950, allow us to trace a hypothetical demographic framework in which three demographic crises of long lasting attributed by scholars to unfavourable social-economic situations or sometimes to war aggression, can be observed. The available volcanological studies and dating of the main eruptions of the Aeolian volcanoes in Holocene time have allowed us to give special attention to the occurrence, in these periods of crisis, of volcanic events that could have had an effect on the local anthropic history.

In summary we hypothesize that:

1. The first crisis that took place in $4^{\text {th }}$ millennium BC was recorded in all the islands and in particular the main Neolithic site of Lipari: Contrada Diana. During the Diana-Spatarella facies, the following is documented: the reduction of the coastal settlement of Contrada Diana, the choice of inhabitants to occupy again the Rocca del Castello, and the development of settlements on areas protected by the activity of the Aeolian volcanoes. This situation suggests that, during the Copper Age, the lowland of the Contrada Diana could be particularly exposed to the volcanic risk caused by direct effects of the Sciara del Fuoco collapse of Stromboli Island (related to sc5a scar of Figure 4) that produced a large tsunami able to affect all archipelago coasts, and by the indirect action of the eruptive activity from the nearby Gran Cratere of Vulcano Island that produced periodic ash fallout and posed a threat to sailors travelling between the mainland and Lipari (Table 1a; Figure 6). Finally, the Gran Cratere of Volcano activity could have been the cause of the reduction of the settlements for the whole period of Copper Age.

2. The second crisis temporally located between ninth and sixth century BC, like the previous one, could be caused by the effects of the strong eruptive phase of the Gran Cratere of Volcano dated $2.9 \mathrm{ka}$ and by any disastrous effects caused by tsunami waves induced by another sector collapse (related to sc5b scar) occurred at the end of the Neostromboli (Table 1a; Figure 6). As during the first crisis, the navigation from mainland to Lipari Island will have been involved making difficult this destination.

3. The third crisis happened in the historical period between the sixth and the eleventh century with a possible peak during the eruption of Monte Pilato, which occurred in $776 \mathrm{AD}$ in the NE sector of the Lipari Island (Table 1b; Figure 7). The complex dynamics of this more recent crisis will be the object of a future study.

The comparison of archaeological and volcanological data in a long-inhabited region as Aeolian archipelagos may help to improve the eruptive history of the volcano and to contribute to solving the enigma of demographic crises observed in the human occupancy of the isles. Even if available knowledges are sufficient to formulate new hypotheses on the origin of these demographic crises, however, additional data will be needed to be confirmed or rejected the thesis illustrated in this paper.

Acknowledgements. Our heartfelt thanks goes to Massimiliano Cascone (INGV of Pisa), for the graphical assistance; to Pietro Lo Cascio (NESOS Association of Lipari); to Claudio Tranne (University of Bologna) and Fabio Speranza (INGV of Rome). We are grateful to William M. Moreland for improving the grammar and readability of the paper.

\section{REFERENCES}

Arena, G.A.M. (1991). Note sull'economia delle Isole Eolie dal Neolitico alla prima metà del XVI secolo d.C., Annali dell'Istituto tecnico commerciale Antonio Maria Jaci di Messina, 2 serie, anno II, Messina. 
Arena, G.A.M. (1995). Popolazione e distribuzione della ricchezza a Lipari nel 1610, Società di Storia Patria Messina 1992, Incontri Meridionali 1-2, Rubbettino.

Arrighi, S., J.C. Tanguy and M. Rosi (2006). Eruptions of the last 2200 years at Vulcano and Vulcanello (Aeolian Islands, Italy) dated by high-accuracy archeomagnetism. Physics of the Earth and Planetary Interiors, 159, 225-233.

Bacci, G.M., M.C. Martinelli, A. Ollà, A. Sardella, M.G. Vanaria and G. Zavettieri (2008). Guida Archeologica delle Isole Eolie. Regione Siciliana, Assessorato dei Beni Culturali, Ambientali e della Pubblica Istruzione, Palermo.

Bernabò Brea, L. (1968-69). Considerazioni sull'Eneolitico e sulla prima età del Bronzo della Sicilia e della Magna Grecia, Kokalos, XIV-XV, Palermo, 20-59.

Bernabò Brea, L. (1988). L'età del Rame nell'Italia insulare: la Sicilia e le Isole Eolie, Rassegna di Archeologia, 7, 469-506.

Bernabò Brea, L. (1989). Le Isole Eolie dal tardoantico ai Normanni, Ravenna.

Bernabò Brea, L. and M. Cavalier (1960). La stazione preistorica della Contrada Diana e la necropoli protostorica di Lipari, Meligunis Lipara, I, Palermo.

Bernabò Brea, L. and M. Cavalier (1968). Stazioni preistoriche delle isole Panarea, Salina e Stromboli, Meligunis Lipára, III, Palermo.

Bernabò Brea, L. and M. Cavalier (1980). L’Acropoli di Lipari nella preistoria , Meligunis Lipara, IV, Flaccovio, Palermo.

Bernabò Brea, L. and M. Cavalier (1991a). Filicudi: insediamenti dell'età del bronzo, Meligunìs Lipára, VI, Palermo.

Bernabò Brea, L. and M. Cavalier (1991b). Isole Eolie. Vulcanologia archeologia, ed. Oreste Ragusi, Milazzo.

Bernabò Brea, L. and M. Cavalier (1991c). Lipari, in Nenci G., Vallet G (eds), Bibliografia topografica della colonizzazione greca in Italia e nelle Isole tirreniche, Scuola Normale Superiore, Ecole Francaise de Rome, Centre J Berard Naples, Pisa-Roma, 81185.

Bernabò Brea, L. and M. Cavalier (2003). Lipari il complesso archeologico delle terme di San Calogero, Quaderni di Archeologia, 4, Università di Messina, ed. Rubbettino, 5-51.

Bernabò Brea, L., M. Cavalier and U. Spigo (1994). Li- pari, Museo Eoliano, Edizioni Novecento, Palermo. Bernabò Brea, L. and W. Kronig (1979). Le isole Eolie dal tardo antico ai Normanni, Archivio Storico Siracusano, (1978-1979), Società di Storia Patria, Siracusa, 25-99.

Bettelli, M., V. Cannavò, A. Di Renzoni, F. Ferranti, S.T. Levi, M.C. Martinelli, A. Ollà, G. Tigano and M. Vidale (2016). L'età del Bronzo a Stromboli: il villaggio terrazzato di San Vincenzo come avamposto nord-orientale dell'arcipelago eoliano, in Cazzella A., Guidi A., Nomi F. (eds) Convegno di studi in memoria di Giorgio Buchner "Ubi minor.. le isole minori del Mediterraneo centrale dal Neolitico ai primi contatti coloniali”, Capri - Anacapri - Ischia 27-29 ottobre 2013, Scienze dell'Antichità, 22.2, Roma, 297-314.

Binder, D., P. Lanos, L. Angeli, L. Gomart, J. Guilaine, C. Manen, R. Maggi, I.M. Muntoni , C. Panelli, G. Radi, C.Tozzi, D. Arobba, J. Battentier, M. Brandaglia, L. Bouby, F. Briois, A. Carré, C. Delhon, L. Gourichon, P. Marinval, R. Nisbet, S. Rossi, P. Rowley-Conwy and S. Thiébault (2017). Modelling the earliest north-western dispersal of Mediterranean Impresse Wares: new dates and Bayesian chronological model, Documenta Praehistorica, XLIV, 54-77.

Bigazzi, G., M. Coltelli and P. Norelli (2003). Nuove età delle ossidiane di Lipari determinate con il metodo delle tracce di fissione. GeoItalia, 4th Forum FIST, Bellaria, 16-18 September, Abstract, 444-446.

Calvari, S., S. Branca et al. (2011). Reconstruction of the eruptive activity on the NE sector of Stromboli volcano: timing of flank eruptions since $15 \mathrm{ka}$. Bulletin of Volcanology, 73, 101-112.

Cavalier, M. (1979), Ricerche preistoriche nell'arcipelago eoliano, Rivista di Scienze preistoriche, XXXIV, 12, Istituto Italiano di Preistoria e protostoria, Firenze, 45-134.

Cavalier, M. (1981). Il villaggio preistorico di San Vincenzo, Sicilia Archeologica, 46-47, Trapani, 27-54.

De Astis, G., P. Dellino, R. De Rosa and L. La Volpe (1997a). Eruptive and emplacement mechanisms of widespread fine-grained pyroclastic deposits on Vulcano Island (Italy). Bulletin of Volcanology, 59,87-102.

De Astis, G., L. La Volpe, A. Peccerillo and L. Civetta (1997b). Volcanological and petrological evolution of Vulcano Island (Aeolian Arc, southern Tyrrhenian Sea). Journal of Geophysical Research, 102, 
8021-8050.

De Astis, G., Dellino, P., La Volpe, L., Lucchi F. and C.A. Tranne,(2013). Geological map of the island of Vulcano, scale 1:10,000 (Aeolian archipelago). In: Lucchi, F., A. Peccerillo, J. Keller, C.A. Tranne and P.L: Rossi, P. L. (eds) The Aeolian Islands Volcanoes. Geological Society, London, Memoirs, 37, enclosed DVD.

De Astis, G., F. Lucchi F., P. Dellino, L. La Volpe, C.A. Tranne, M.L. Frezzotti and A. Peccerillo ( 2013). Geology, volcanic history and petrology of Vulcano (central Aeolian archipelago). Geological Society, London, Memoirs, doi: 10.1144/M37.11, v.37; 281-349.

D’Oronzo, C., C. Speciale, A. Stellati, M.C. Martinelli, G. Fiorentino (2018) . Adattamento e resilienza in ambiente insulare: il caso studio delle isole Eolie, Rivista di Scienze Preistoriche, Istituto Italiano di Preistoria e Protostoria, Firenze, in press.

Fiorentino, G., M. Caldara, V. De Santis, C. D’Oronzo, I.M. Muntoni, O. Simone, M. Primavera and F. Radina (2013). Climate changes and human-environment interactions in the Apulia region of southeastern Italy during the Neolithic period, The Holocene, 1298-1317. http://hol.sagepub.com/content/23/9/1297

Foresta Martin, F. and M. La Monica (2017). The black gold that came from the sea. A rewiew ok obsidian studies at the Island of Ustica, Italy. Miscellanea INGV,37, 6-7.

Forni, F., F. Lucchi, A. Peccerillo, C.A. Tranne, P.L. Rossi and M.L. Frezzotti (2013). Stratigraphy and geological evolution of the Lipari volcanic complex (central Aeolian Archipelago), in Lucchi F. et al. (eds), The Aeolian Islands Volcanoes. Geological Society Memoirs, 37, The Geological Society, London, 213-279.

Francalanci, L., F. Lucchi, J. Keller, G. De Astis and C.A. Tranne (2013). Eruptive, volcano-tectonic and magmatic history of the Stromboli volcano (northeastern Aeolian archipelago). Chapter 13 Geological Society, London, Memoirs 2013, doi: 10.1144/M37.13; v.37, 397-471.

Frazzetta, G., P. Y. Gillot, and L. La Volpe (1985). The Island of Vulcano. IAVCEI Scientific Association Excursion Guidebook, 125-140.

Gillot, P. Y. (1987). Histoire volcanique des Iles Eoliennes: arc insulaire ou complexe orogénique anulaire? Documents et Travaux, Institut Géologique
Albert-de-Lapparent, Paris, 11, 35-42.

Guidoboni, E., G. Ferrari, D. Mariotti, A. Comastri, G. Tarabusi, G. Sgattoni, G. Valensise (2018) CFTI5Med, Catalogo dei Forti Terremoti in Italia (461 a.C.-1997) e nell'area Mediterranea (760 a.C.1500). Istituto Nazionale di Geofisica e Vulcanologia (INGV). http://storing.ingv.it/cfti/cfti5/.

Iacolino, G. (2007). Le isole Eolie nel risveglio delle memorie sopite, esame dei testimoni. Archivio Vescovile di Lipari, Aldo Natoli Editore, Lipari.

Kapitan, G. (2003). Come navigavano nel Neolitico, Atti della XXXV Riunione Scientifica Istituto Italiano di Preistoria e Protostoria "Le comunità della preistoria italiana. Studi e ricerche sul Neolitico e l'età dei metalli”, Lipari 2-7 giugno 2000, Firenze, 10381041.

Keller, J. (1970). Datierung derobsidiane und bimstuffe von Lipari. Neues Jahrbuch für Geologie und Palaeontologie Monatshefte, 1, 90-101.

Keller, J. (2002). Lipari's fiery past: dating the medieval pumice eruption of Monte Pelato: International Conference 'The fire between air and water', UNESCO-Regione Siciliana, Lipari, September 29thOctober 2nd, oral presentation.

Levi, S.T., M. Bettelli, A. Di Renzoni and M.C. Martinelli (2011). 3500 anni fa sotto il vulcano. La ripresa delle indagini nel villaggio protostorico di San Vincenzo a Stromboli, Rivista Scienze Preistoriche, LXI, Istituto Italiano di Preistoria e Protostoria, Firenze, 157-172.

Levi, S. T., M. Bettelli, V. Cannavò, A. Di Renzoni, F. Ferranti, M.C. Martinelli, A. Ollà and G. Tigano. (2017). Stromboli: gateway for early Mycenaean connections through the Strait of Messina. Hesperos the Aegean seen from the West, Proceedings of the 16th International Aegean Conference, University of Ioannina, Department of History and Archaeology, Unit of Archaeology and Art History, 18-21 May 2016, Liege, 147-154.

Lucchi, F., A. Peccerillo, J. Keller, C.A. Tranne and P.L. Rossi (2013). The Aeolian Island Volcanoes. Geological Society, London, Memoirs, 37.

Lucchi, F., C.A. Tranne , F. Forni , P.L. Rossi (2013). Geological map of the island of Lipari, scale 1:10,000 (Aeolian archipelago). In: Lucchi, F., A. Peccerillo, J. Keller, C.A. Tranne and P.L. Rossi (eds) The Aeolian Islands Volcanoes. Geological Society, London, Memoirs, 37, enclosed DVD.

Lucchi, F., J. Keller, G. De Astis, L. Francalanci and C.A. 
Tranne (2013). Geological map of the island of Stromboli, scale 1:10,000 (Aeolian archipelago). In: Lucchi, F., A. Peccerillo, J. Keller, C.A. Tranne. and P.L. Rossi (eds) The Aeolian Islands Volcanoes. Geological Society, London, Memoirs, 37, enclosed DVD.

Maniscalco, L.(2000). Il neolitico attorno alla piana di Catania: l'insediamento preistorico presso Le Salinelle di San Marco (Paternò). From A. Pessina and G. Muscio (eds) La Neolitizzazione tra Oriente e Occidente. Convegno di Studi Udine 1999, Museo Friuliano di Storia Naturale, Udine, 489-507.

Manni, M. (2015). Contributo storiografico alla datazione della Sciara del Fuoco dello Stromboli. Quaderni di Geofisica, 130, 1-50.

Martinelli, M.C. (2001). Un'altra capanna nella località Spatarella a Lipari (Messina)?, in M.C. Martinelli, U. Spigo (eds), Studi di preistoria e protostoria in onore di L. Bernabò Brea, Quaderni del Museo Eoliano, 4, Assessorato dei Beni Culturali, Ambientali e della Pubblica Istruzione, Messina, 89-112.

Martinelli, M.C. (2005). Il Villaggio dell'età del Bronzo medio di Portella a Salina nelle Isole Eolie, Origines, Istituto Italiano di Preistoria e Protostoria, Firenze.

Martinelli, M.C. (2010). Archeologia delle Isole Eolie. Il villaggio dell'età del Bronzo medio di Portella a Salina nelle Isole Eolie. Scavi 2006 e 2008, Milano.

Martinelli, M.C., G. Fiorentino, B. Prosdocimi, C. d'Oronzo, S.T. Levi, G. Mangano, A. Stellati and N. Wolff (2010). Nuove ricerche nell'insediamento sull'istmo di Filo Braccio a Filicudi. Nota preliminare sugli scavi 2009, Origini, 32, 285-314.

Martinelli, M. C. (2016). Updates on the cultural and chronological framework of the prehistory and protohistory of the Aeolian Islands: from the first settlement to the end of the villages, in Cazzella A., Guidi A., Nomi F. (eds) Convegno di studi in memoria di Giorgio Buchner "Ubi minor.. le isole minori del Mediterraneo centrale dal Neolitico ai primi contatti coloniali”, Capri - Anacapri - Ischia 27-29 ottobre 2013, Scienze dell'Antichità, 22.2, Roma, 263-279.

Martinelli, M.C., F. Cannizzaro and M. Gusmano (2014). Considerazioni sulla facies di Malpasso nella cuspide orientale della Sicilia e nelle isole Eolie, Rivista di Scienze Preistoriche, LXIV, Istituto Italiano di Preistoria e Protostoria, Firenze, 151-192.

Pagliara, M. (1995). Fonti per la storia dell'arcipelago eo- liano in età greca. Con un'appendice sull'epoca romana. Meligunis Lipara VIII, parte seconda, Accademia di Scienze Lettere e Arti, Palermo.

Pessina A. and V. Tinè (2012), Archeologia del Neolitico. L'Italia fra il VI e IV millennio a.C., Carrocci, Roma. Risica, G., F. Speranza, G. Giordano, G. De Astis and F. Lucchi (2017). Paleomagnetic Dating of the Neostromboli Sequence. Miscellanea INGV, 37, 73-74.

Rosi, M., A. Bertagnini and P. Landi (2000). Onset of the persistent activity at Stromboli volcano (Italy). Bulletin of Volcanology, 62, 294-300.

Soligo, M., G. De Astis, M.C. Delitala, L. La Volpe, A. Taddeucci and P. Tuccimei (2000). Uranium-series disequilibria in the products from Vulcano Island (Sicily, Italy): isotopic chronology and magmatological implications. Acta Vulcanologica, 12, 49-59.

Speranza, F., M. Pompilio, F. D’Ajello Caracciolo and L. Sagnotti (2008). Holocene eruptive history of the Stromboli volcano: constraints from paleomagnetic dating. Journal of Geophysical Research, 113, B09101.

Tanguy, J.C., M. Le Goff, C. Principe, S. Arrighi, V. Chillemi, A. Paiotti, S. La Delfa and G. Patane' (2003). Archeomagnetic dating of Mediterranean volcanics of the last 2100 years: validity and limits. Earth and Planetary Science Letters, 211, 121123.

Tibaldi, A. (2001). Multiple sector collapses at Stromboli volcano, Italy: how they work. Bulletin Volcanology 63: 112-125.

Tinè, V. and E. Natali (2014). Il Neolitico medio in Calabria settentrionale, Rivista di Studi Liguri, LXXVII-LXXIX (2011-2013), 515-520.

Tinti, S., G. Pagnottoni, F. Zaniboni and E. Bortolucci (2002). Tsunami generation in Stromboli island and impact on the south-east Tyrrehenian coasts. 2, Dipartimento di Fisica, Università di Bologna, Bologna, Italy, 301-308.

Voltaggio, M., M. Branca, P. Tuccimei and F. Tecce (1995). Leaching procedure used in dating young potassic volcanic rocks by the 226Ra/230Th method. Earth Planetary and Science Letters, 136, 123-131.

Zagari, F. (2015). Le isole Eolie in epoca bizantina. Primi dati di una rilettura topografica, P. Arthur and M.L. Imperiale (eds) VII Congresso Nazionale di archeologia medievale, Lecce 9-12 settembre 2015, II, 
MANNI ET AL.

All'Insegna del Giglio, Firenze, 454-458.

Zanchetta, G., R. Sulpizio et al. (2011). Tephrostratigraphy, chronology and climatic events of the Mediterranean basin during the Holocene: an overview. The Holocene, 21, 33-52.

CORRESPONDING AUTHOR: Marco MANNI Istituto Nazionale di Geofisica e Vulcanologia - Osservatorio Etneo Catania, Italy email: marco.manni@ingv.it (c) 2019 the Istituto Nazionale di Geofisica e Vulcanologia. All rights reserved 